\title{
Tajemnica adwokacka w katalogu regut wyznaczających wzorcowy model wykonywania zawodu adwokata
}

\begin{abstract}
Streszczenie
Tajemnica adwokacka jest jednym z najważniejszych atrybutów pracy prawnika. Jako sztandarowy wyznacznik reguł wskazujących na wzorcowe wykonywanie zawodu adwokata podlegał kilku zmianom, które miały jeszcze pełniej wyznaczać standardy należytego zachowania przedstawicieli tej grupy zawodów prawniczych. Ideały przyświecające pracy adwokata, a opisane w Zbiorze Zasad Etyki Adwokackiej i Godności Zawodu wywodzą się z początków samorządu, który odrodził się w II Rzeczypospolitej. Założenia twórców samorządu adwokackiego zmierzały do społecznego uznania zawodu adwokata i jego roli w porządku prawnym. Właśnie z tego powodu tak istotne jest kreowanie oraz dbanie o wizerunek zawodowy. Adwokaci i aplikanci tworzą nie tylko grupę zawodową, ale także wspólnotę, którą łączy historia, która wyznaje te same wartości i kieruje się własnymi zasadami.
\end{abstract} Słowa kluczowe: tajemnica adwokacka, adwokat, Zbiór Zasad Etyki Adwokackiej i Godności Zawodu, profesjonalizm pracy adwokata.

Celem, do którego adwokat dąży - jest przekonanie sędziów... Sędziów zaś może ująć tylko ten, kogo uważają za człowieka prawego... Pod żadnym więc pozorem nie powinien adwokat wystawiać na szwank zaufania, które wzbudza.

Fernand Payen, O powołaniu adwokatury i sztuce obrończej

Zbiór Zasad Etyki Adwokackiej i Godności Zawodu (Kodeks Etyki Adwokackiej) ${ }^{1}$ został uchwalony przez Naczelną Radę Adwokacką 10 października 1998 r. Jako sztandarowy wyznacznik reguł wskazujących na wzorcowe wykonywanie zawodu

1 Zbiór Zasad Etyki Adwokackiej i Godności Zawodu (Kodeks Etyki Adwokackiej) został uchwalony przez Naczelną Radę Adwokacką [dalej: NRA] 10 października 1998 r. (uchwała nr 2/XVIII/98) ze zmianami wprowadzonymi uchwałą NRA nr 32/2005 z 19 listopada 2005 r., uchwałami NRA nr 33/2011 - 54/2011 z 19 listopada 2011 r. oraz uchwałą nr 64/2016 NRA z 25 czerwca 2016 r.; tj. na podstawie uchwaty nr 52/2011 NRA z 19 listopada 2011 r. obwieszczony 27 lutego 2018 r. 
adwokata podlegał kilku zmianom, które miały jeszcze pełniej wyznaczać standardy należytego zachowania przedstawicieli tej grupy zawodów prawniczych. Uchwała wprowadziła normy, które mają zastosowanie jako tzw. przepisy ogólne, wskazała dyrektywy odnoszące się do wykonywania zawodu, a także opisała modelowy stosunek do sądu i innych organów, przed którymi występuje adwokat. Bardzo rozbudowane są nadto reguły związane ze stosunkiem adwokata do kolegów czy klientów. Ważnym elementem składowym omawianej uchwały jest rozdział dotyczący pracy w samorządzie oraz stosunku do władz adwokatury. Palestra bowiem od zawsze podkreślała doniosłość pracy swoich przedstawicieli na rzecz obywateli oraz organów społeczności adwokackiej.

Ideały przyświecające pracy adwokata, a opisane w Zbiorze Zasad Etyki Adwokackiej i Godności Zawodu wywodzą się z początków samorządu, który odrodził się w II Rzeczypospolitej na mocy dekretu w przedmiocie Statutu Tymczasowego Palestry Państwa Polskiego ${ }^{2}$. Regulacja weszła w życie 1 stycznia 1919 r., natomiast pierwsze rady adwokackie w Warszawie i Lublinie ukonstytuowały się trzy miesiące później wraz z pierwszą Naczelną Radą Adwokacką, którą wybrano w marcu i kwietniu 1919 r. $^{3}$

Idee i założenia przyświecające twórcom samorządu adwokackiego zmierzały do społecznego uznania zawodu adwokata i jego roli w porządku prawnym. Osoba wykonująca ten zawód nie tylko winna przejawiać wiedzę powszechną oraz prawniczą, ale także wzbudzać poszanowanie społeczne z uwagi na przymioty moralne oraz pozytywny wizerunek wśród społeczeństwa. Jako przedstawiciele inteligencji narodu polskiego adwokaci winni dbać o interes prawny swoich mandatów, a nadto rzetelnością wykonywanej profesji - wzbudzać zaufanie oraz powszechny szacunek.

Tego rodzaju wizja zawodu adwokata oraz jego roli społecznej przyświecała także Naczelnej Radzie Adwokackiej, która 10 października 1998 r. zdecydowała o podjęciu uchwały o Zbiorze Zasad Etyki Adwokackiej i Godności Zawodu.

Uchwała reguluje szereg kwestii związanych $\mathrm{z}$ wykonywaniem tego zawodu prawniczego, w tym dotyczących sposobu jego realizacji. Wprowadza ponadto liczne zasady ogólne. Rozdziały pierwszy oraz drugi opisują postanowienia ogólne, a także zasady wykonywania zawodu adwokata. W rozdziale trzecim opisane są dyrektywy wskazujące na poprawny stosunek do sądów i innych organów, przed którymi występuje adwokat. Wspomina się tu o modelowym stosunku dbania o dobro klienta, przy poszanowaniu godności sądu oraz przeciwników procesowych. Znamienny jest zapis o konieczności powściągnięcia działań oczekiwanych przez klienta, gdyby były one sprzeczne z zasadami etyki i godnością

2 Dekret Naczelnika Państwa Józefa Piłsudskiego w przedmiocie Statutu Tymczasowego Palestry Państwa Polskiego (Dz.PrP.P. z 1918 r. Nr 22 poz. 75).

3 A. Redzik, Historia samorzqdu adwokatury polskiej, http://www.adwokatura.pl/100-lecieadwokatury/historia-samorzadu-adwokatury-polskiej/ (dostęp: 27.02.2020). 
wykonywanego zawodu $(\$ 10)$. W rozdziale czwartym opisano wzorcowy sposób odnoszenia się do kolegów, a w piątym - wobec klientów. Kolejny rozdział wskazuje na ważki aspekt pracy adwokata na rzecz samorządu i wspierania go własnymi działaniami, w tym określa należyty stosunek do władz adwokatury. Przepisy końcowe zamykają rozważania związane $\mathrm{z}$ akceptowalnym sposobem wykonywania tego zawodu prawniczego.

Jedną z najważniejszych reguł opisanych w Kodeksie Etyki Adwokackiej jest zasada tajemnicy zawodowej. Znajduje się ona w rozdziale drugim dotyczącym wytycznych wykonywania tego zawodu.

W literaturze zagadnienie tajemnicy zawodowej rozumiane jest jako prawo do wejścia w posiadanie sekretu oraz obowiązek utrzymania go w bezwzględnej poufności. Tajemnica ta jest zatem jednocześnie prawem profesjonalnego przedstawiciela procesowego, ale przede wszystkim obowiązkiem wobec klienta ${ }^{4}$.

Tajemnica adwokacka i zakazy dowodowe związane z możliwością przesłuchania adwokata w charakterze świadka mają ponadto swoje gwarancje w aktach prawnych bezpośrednio odnoszących się do zawodu adwokata. Zasadnicze znaczenie dla prawidłowego wykonywania funkcji adwokackich ma uregulowanie przyjęte w art. 6 Prawa o adwokaturze ${ }^{5}$, dotyczące zakresu i charakteru tajemnicy zawodowej adwokata. Artykuł 6 p.o.a. stanowi, iż adwokat obowiązany jest zachować w tajemnicy wszystko, o czym się dowiedział w związku z udzielaniem pomocy prawnej, a ten obowiązek nie jest ograniczony w czasie. Treść tego przepisu wskazuje nadto, iż adwokata nie można zwolnić z obowiązku zachowania tajemnicy zawodowej odnośnie do faktów, o których dowiedział się, udzielając pomocy prawnej lub prowadząc sprawę. Tego rodzaju wyłączenie ustawowe nie dotyczy jednak informacji udostępnianych na podstawie ustawy z dnia 16 listopada $2000 \mathrm{r}$. o przeciwdziałaniu praniu pieniędzy oraz finansowaniu terroryzmu $u^{6}$. Wyłączenie powyższe odnosi się ponadto do informacji przekazywanych na podstawie przepisów rozdziału 11 a działu III ustawy z dnia 29 sierpnia 1997 r. Ordynacja podatkowa ${ }^{7}$. W obydwu przypadkach klauzula wyłączająca odnosi się do zakresu wskazanego tymi przepisami.

Natomiast Zbiór Zasad Etyki i Godności Zawodu uchwalony przez Naczelną Radę Adwokacką w $\$ 19$, w sposób szczegółowy w stosunku do uregulowań ustawowych, określił obowiązki adwokata w zakresie zachowania tajemnicy zawodowej. Sprowadzają się one nie tylko do zachowania w tajemnicy oraz zabezpieczenia przed ujawnieniem lub niepożądanym wykorzystaniem wszystkiego, o czym adwokat dowiedział się w związku z wykonywaniem obowiązków służbowych, ale

4 J. Naumann, Zbiór Zasad Etyki Adwokackiej i Godności Zawodu. Komentarz, Warszawa 2017.

5 Ustawa z dnia 26 maja 1982 r. Prawo o adwokaturze (Dz.U. z 1982 r. Nr 16 poz. 124; tj. Dz.U. z 2019 r. poz. 1513, 1673, 2020) [dalej: p.o.a.].

7 Dz.U. z 2019 r. poz. 900, 924, 1018. 
nadto do objęcia tajemnicą adwokacką materiałów znajdujących się w aktach adwokackich ( $\$ 19$ ust. 1 i 2). Obowiązek przestrzegania tajemnicy zawodowej jest nieograniczony w czasie.

Te jakże znamienne zasady związane $\mathrm{z}$ wykonywaniem zawodu adwokata posiadają ponadto swoje ustawowe zabezpieczenie w regulacjach w postaci gwarancji procesowych. Postępowanie cywilne co do zasady zezwala na dopuszczenie dowodu z przesłuchania każdego, kto może mieć wiedzę na temat istotnych okoliczności sprawy. Wezwany w charakterze świadka adwokat lub radca prawny może jednak skorzystać z prawa odmowy odpowiedzi na pytanie, jeżeli jego zeznania mogłyby wiązać się z pogwałceniem istotnej tajemnicy zawodowej - art. $261 \S 2$ Kodeksu postępowania cywilnego ${ }^{8}$. W takiej sytuacji organ dokonujący przesłuchania nie może oczekiwać ani zażądać odpowiedzi na zadane pytanie przy wskazaniu przez adwokata lub radcę prawnego na swoje prawo wynikające $z$ owej tajemnicy.

W postępowaniu karnym zakaz niezupełny bezwzględny związany z brakiem możliwości przesłuchania jako świadka obrońcy albo adwokata czy radcy prawnego, który ma kontakt z osobą zatrzymaną w trybie procesowym, wynika z treści art. 178 pkt 1 Kodeksu postępowania karnego 9 . Jest to zakaz przesłuchania tych osób w charakterze świadków co do faktów i okoliczności, o których dowiedziały się, udzielając porady prawnej lub prowadząc sprawę. Omawiany przepis gwarantuje zatem adwokatowi lub radcy prawnemu ochronę informacji pozyskanych od klienta, któremu udzielano pomocy prawnej w związku z jego zatrzymaniem tudzież w ramach realizowanego prawa do obrony przysługującego podejrzanemu oraz oskarżonemu. Innymi słowy - występuje w tym zakresie korelacja faktycznej możliwości realizacji prawa do obrony, albowiem adwokata/radcy prawnego nie można przesłuchać na temat tych faktów, o których dowiedział się, reprezentując osobę, której takie prawo do obrony przysługuje. Zakaz dowodowy zabezpiecza osobę zatrzymaną lub stronę postępowania przed ujawnieniem informacji, które mogłyby pogorszyć jej sytuację procesową w związku z przesłuchaniem adwokata/radcy prawnego na tę właśnie okoliczność. Organy procesowe respektując prawo do odmowy złożenia wyjaśnień przez podejrzanego/oskarżonego (prawo do odmowy udzielenia odpowiedzi na pytania osoby zatrzymanej), nie mogą w zamian przesłuchać adwokata/radcy prawnego udzielającego pomocy prawnej zatrzymanemu lub obrońcy na temat tychże okoliczności, które przemilczał zatrzymany lub podejrzany/oskarżony. Jak wynika z nazwy tego zakazu - jest to zakaz bezwzględny, który nie może zostać uchylony przez jakikolwiek organ procesowy. W tym bowiem zakresie porządek prawny czyni szczególne gwarancje podmiotom zatrzymanym i tym, wobec których prowadzone jest postępowanie karne, jednakże chronionych prawem do obrony. Zakaz

8 Ustawa z dnia 17 listopada 1964 r. Kodeks postępowania cywilnego (Dz.U. z 1964 r. Nr 43 poz. 296; tj. Dz.U. z 2019 r. poz. 1460, 1469, 1495, 1649,1655) [dalej: k.p.c.].

9 Ustawa z dnia 6 czerwca 1997 r. Kodeks postępowania karnego (Dz.U. Nr 89 poz. 556 ze zm.) [dalej: k.p.k.]. 
chroni tzw. tajemnicę obrończą i nie jest istotne, kto pełnił tę funkcję (adwokat/radca prawny). Na gruncie art. 178 pkt 1 k.p.k. nie chodzi przy tym wyłącznie o obrońcę z postępowania karnego, ale o każdego obrońcę, którego nie wolno tu przesłuchiwać jako świadka co do faktów, o których dowiedział się, udzielając porady prawnej albo prowadząc sprawę. Zakaz odnosi się z założenia - poza wskazanym wyjątkiem udzielenia porady prawnej zatrzymanemu - do obrońcy, a nie do adwokata w ogóle. W tym ostatnim przypadku ochrony tajemnicy zawodowej adwokata upatrywać należy w art. $180 \$ 2$ k.p.k.

Tym samym tajemnica zawodowa chroniona jest także przez pryzmat art. $180 \$ 2$ k.p.k., kiedy to osoba zobowiązana do zachowania m.in. tajemnicy adwokackiej może zostać przesłuchana co do faktów objętych tą tajemnicą tylko wtedy, gdy jest to niezbędne dla dobra wymiaru sprawiedliwości, a okoliczność nie może być ustalona na podstawie innego dowodu. Należy podkreślić w tym miejscu fakt, iż takie przesłuchanie nie może dotyczyć okoliczności objętych zakazem wiedzy obrończej lub w związku z zatrzymaniem procesowym. W tym bowiem zakresie zakaz ma charakter bezwzględny (art. 178 pkt. 1 k.p.k.). Co warte zaznaczenia, uchylenie tajemnicy zawodowej może być związane jedynie w zakresie innych czynności aniżeli opisane w art. 178 pkt. 1 k.p.k., czyli związanych chociażby ze sprawami o charakterze innym niż obrończe, np. cywilnymi, rodzinnymi, gospodarczymi.

W razie konieczności uchylenia tajemnicy zawodowej w postępowaniu przygotowawczym w przedmiocie przesłuchania lub zezwolenia na przesłuchanie decyduje o tym sąd, na posiedzeniu bez udziału stron, w terminie nie dłuższym niż siedem dni od daty doręczenia wniosku prokuratora. Zakres zwolnienia z tajemnicy zawodowej powinien być precyzyjnie wytyczony w treści postanowienia wydanego na podstawie art. $180 \$ 2$ k.p.k. Wyznaczenie zakresu musi odnosić się do ściśle określonej sprawy, zachowania oraz sytuacji, co do której osoba ma zostać poddana przesłuchaniu. W wypadku niespełnienia tej przesłanki zwolnienie z tajemnicy zawodowej musiałoby zostać uznane za nieograniczone, dające pełną swobodę działania organom procesowym, co stoi w opozycji do unormowania wynikającego z treści art. $180 \$ 2$ k.p.k. ${ }^{10}$ Oczywiste jest, iż organ procesowy posiadający niczym nieograniczoną swobodę przy przesłuchaniu mógłby $\mathrm{w}$ takim przypadku wykorzystać wskazane osobowe źródło dowodowe w sposób sprzeczny z celem wprowadzenia do polskiego procesu karnego omawianego ograniczenia dowodowego. Sąd winien w takim przypadku wyjątkowo restrykcyjnie opisać zakres dopuszczalnego poszukiwania dowodu.

Wskazać w tym miejscu należy, iż dla adwokata lub radcy prawnego - niezależnie od ustawowych wyłączeń tajemnicy zawodowej - obowiązek zachowania tajemnicy jest etycznie bezwzględny. Wynika $\mathrm{z}$ tego, iż nawet jeśli przepisy

10 Postanowienie SN z 31 stycznia 2019 r. (sygn. akt VI KZ 2/19), www.sn.pl/orzecznictwo (dostęp: 20.03.2020). 
dopuszczają możliwość zwolnienia adwokata z tajemnicy zawodowej, to ma on moralny obowiązek ją zachować, i to nawet w przypadku zwolnienia $\mathrm{z}$ niej przez klienta. Ponadto adwokat lub radca prawny winien mieć na uwadze także i taką okoliczność, zgodnie ze stanowiskiem Sądu Najwyższego, iż adwokatowi lub radcy prawnemu, który szanując bezwzględny zakaz ujawnienia informacji uzyskanych od klienta, odmówi złożenia zeznań, pomimo zwolnienia go z tej tajemnicy przez sąd, nie można skutecznie postawić zarzutu zatajenia prawdy ${ }^{11}$. Właściwe świadczenie pomocy prawnej przez adwokatów lub radców prawnych jest wszakże związane z zaufaniem oraz dyskrecją, jak również wyznacza jedną z ważniejszych podstaw prawidłowego procesu karnego.

Sytuacja uchylenia tajemnicy zawodowej najczęściej ma miejsce w wyniku złożonego wniosku prokuratorskiego lub następczo oskarżyciela publicznego. Jako uosobienie organu ustawowo powołanego do ścigania przestępstw dąży on do realizacji zasady legalizmu oraz zasady prawdy materialnej. Podstawą wszelkich decyzji procesowych winny być zatem ustalenia faktyczne, do których organ dochodzi poprzez przeprowadzane dowody. Jak wcześniej wspomniano, adwokat lub radca prawny winien w każdym przypadku powołania go w charakterze świadka w celu ujawnienia okoliczności, o których dowiedział się w związku z prowadzeniem sprawy lub udzielaniem porady prawnej, odmówić złożenia zeznań, powołując się na wiążącą go tajemnicę zawodową. Takie zachowanie chronione jest prawnie, a wyjątkowe nawet uchylenie tajemnicy zawodowej przez sąd nie będzie wiązało się następczo z odpowiedzialnością w tym zakresie. Oczywiście pamiętać należy także o bezwzględnej tajemnicy obrończej, która w tym zakresie nigdy nie może zostać uchylona $\mathrm{z}$ racji gwarancji wskazanych $\mathrm{w}$ art. 178 pkt. 1 k.p.k.

Do złożenia zeznań przez adwokata lub radcę prawnego dążyć może jednak nie tylko organ procesowy, lecz także inny adwokat, który w tezie wniosku dowodowego wskazuje te okoliczności, które objęte są tajemnicą zawodową. Realizując kroki działania na korzyść swojego klienta, rozpoczyna tym samym tryb ujawnienia informacji objętych szczególną ochroną. W takim przypadku należy wyjątkowo restrykcyjnie podchodzić do sytuacji, kiedy przedstawiciel tego samego zawodu, poniekąd zgodnie z obowiązującym porządkiem prawnym, próbuje ujawnić informacje objęte tajemnicą zawodową.

Przede wszystkim podkreślenia wymaga fakt, iż tego rodzaju działanie adwokata jest czynnością wypełniającą znamiona przewinienia dyscyplinarnego. Treść $₫ 19$ Kodeksu Etyki Adwokackiej wskazuje, iż adwokatowi nie wolno zgłaszać dowodu z zeznań świadka będącego adwokatem lub radcą prawnym w celu ujawnienia przez niego wiadomości uzyskanych $\mathrm{w}$ związku z wykonywaniem zawodu. Jeżeli bowiem adwokat zgłosi dowód z zeznań świadka, będącego adwokatem, w celu, o którym mowa w $\$ 19$ ust. 8 Zbioru Zasad Etyki Adwokackiej i Godności Zawodu in fine, to spełnione są wtedy ustawowe znamiona przewinienia dyscyplinarnego ${ }^{12}$.

11 Uchwała składu siedmiu sędziów SN z dnia 22 stycznia 2003 r. (I KZP 39/02, LEX nr 57084).

12 Postanowienie SN z dnia 12 grudnia 2014 r. (SDI 44/14). 
Zachowanie, o którym mowa w $\$ 19$ ust. 8 Zbioru Zasad Etyki Adwokackiej i Godności Zawodu, jest przewinieniem dyscyplinarnym, opisanym w art. 80 p.o.a. Potrzebę wprowadzenia szczególnej regulacji odpowiedzialności dyscyplinarnej w określonych wspólnotach wskazał Trybunał Konstytucyjny, stwierdzając, że wyodrębnienie procedur odpowiedzialności dyscyplinarnej i nadanie im pozasądowego charakteru znajdować może podstawę w specyfice poszczególnych grup zawodowych oraz ochronie ich autonomii i samorządności. Trybunał podkreślił również, że orzecznictwo dyscyplinarne jest elementem pieczy sprawowanej przez samorząd adwokacki nad członkami korporacji ${ }^{13}$. Trybunał Konstytucyjny konsekwentnie uznaje odpowiedzialność dyscyplinarną za odpowiedzialność represyjną i - nie definiując jej zakresu - wskazuje pewne ogólne gwarancje, które muszą mieć w niej zastosowanie.

Na gruncie odpowiedzialności dyscyplinarnej, uregulowanej w p.o.a., nie obowiązuje zasada nullum crimen sine lege. Podobnie jak jest to w innych wspólnotach poddanych odpowiedzialności dyscyplinarnej, nie ma zamkniętego katalogu przewinień dyscyplinarnych adwokatów i aplikantów adwokackich, ponieważ podstawą odpowiedzialności są czyny godzące w dobro danego zawodu czy też godność związaną z wykonywaniem zawodu adwokata ${ }^{14}$. Prawo o adwokaturze nie zawiera i nigdy nie zawierało definicji przewinienia dyscyplinarnego adwokata i aplikanta adwokackiego. Stworzenie takiego katalogu nie byłoby możliwe nie tylko z uwagi na użycie przez ustawodawcę przepisów blankietowych czy klauzul generalnych, lecz także wielość i różnorodność zachowań, które mogą stanowić delikty dyscyplinarne $^{15}$.

Powyższe udowadnia, iż zachowanie tajemnicy adwokackiej jest jednym z ważniejszych obowiązków adwokata. Jak wskazano w postanowieniu Sądu Najwyższego z dnia 15 listopada 2012 r. $^{16}$, tajemnica zawodowa radcy prawnego, jako obejmująca wszystko, o czym dowiedział się on w związku z udzielaniem porady prawnej i prowadzeniem sprawy, wyklucza możliwość złożenia przez niego zeznań w charakterze świadka w postępowaniu karnym, w którym stroną jest osoba reprezentowana przez niego uprzednio w innych postępowaniach, bez wcześniejszego zwolnienia go od zachowania tajemnicy przez sąd w trybie określonym w art. 180 $\$ 2$ k.p.k. Dotyczy to także sytuacji, gdyby miał zeznawać na prośbę swojego klienta i w jego interesie odnośnie do okoliczności, które były przedmiotem jawnego procedowania przez sądy w sprawach innych niż karne, a tym bardziej gdyby dotyczyło to okoliczności związanych z pertraktacjami między stronami tamtego

13 Wyrok TK z dnia 8 grudnia 1998 r. (K 41/97, OTK ZU 1998 Nr 7 poz. 117).

14 Wyrok TK z dnia 9 listopada 1993 r. (K 11/93, OTK ZU 1993 Nr 2 poz. 37).

15 K. Ceglarska-Piłat, J. Trela, M. Zbrojewska, Prawo o adwokaturze. Komentarz, Warszawa 2016, komentarz do art. 80 p.o.a.

16 Postanowienie SN z dnia 15 listopada 2012 r. (SDI 32/12, OSNSD 2012, poz. 49, s. 193-198, LEX nr 1231613). 
postępowania (a obecnie procesu karnego) i wzajemnych ich stosunków, gdyż tajemnica zawodowa radcy prawnego stanowi dobro samo w sobie, jako element prawidłowego i etycznego wykonywania tej profesji. Wskazane powyżej argumenty bezspornie odnoszą się w sposób tożsamy do tajemnicy adwokackiej.

Przywilej tajemnicy zawodowej i obowiązek jej dotrzymania to nieodłączne atrybuty zawodu adwokata i radcy prawnego. To właśnie na tym elemencie fiducji zasadza się kluczowe dla tych zawodów zaufanie pomiędzy adwokatem lub radcą prawnym a klientem. Tajemnica zawodowa wyznacza granicę, która rozdziela sferę ingerencji organów władzy publicznej. Właśnie z tego powodu tak istotne jest kreowanie oraz dbanie o wizerunek zawodowy. Adwokaci i aplikanci tworzą nie tylko grupę zawodową, ale także wspólnotę, którą łączy historia, która wyznaje te same wartości i kieruje się własnymi zasadami. Do najważniejszych z nich należą solidarność, uczciwość zawodowa oraz poszanowanie tajemnicy zawodowej. Dbanie o ich przestrzeganie to kluczowe motto, które można wyrazić takimi słowami: „tajemnica - tak jak prawda - albo obowiązuje w formie kategorycznej, albo jej w ogóle nie ma. Tak jak nie ma ćwierć- czy półprawdy, tak nie ma miejsca na częściową, czyli względną tajemnicę"17.

\section{Bibliografia}

\section{Literatura}

Ceglarska-Piłat K., Trela J., Zbrojewska M., Prawo o adwokaturze. Komentarz, Wolters Kluwer, Warszawa 2016.

Krzemiński Z., Etyka adwokacka. Teksty, orzecznictwo, komentarz, Wolters Kluwer, Warszawa-Kraków 2008.

Naumann J., Zbiór Zasad Etyki Adwokackiej i Godności Zawodu. Komentarz, C. H. Beck, Warszawa 2017.

\section{Akty prawne}

Dekret Naczelnika Państwa Józefa Piłsudskiego w przedmiocie statutu tymczasowego Palestry Państwa Polskiego (Dz.Pr.P.P. z 1918 r. Nr 22 poz. 75).

Ustawa z dnia 17 listopada 1964 r. Kodeks postępowania cywilnego (Dz.U. z 1964 r. Nr 43 poz. 296; tj. Dz.U. z 2019 r. poz. 1460).

Ustawa z dnia 26 maja 1982 r. Prawo o adwokaturze (Dz.U. z 1982 r. Nr 16 poz. 124; tj. Dz.U. z 2019 r. poz. 1513, 1673, 2020).

17 Z. Krzemiński, Etyka adwokacka. Teksty, orzecznictwo, komentarz, Warszawa-Kraków 2008, s. 89. 
Ustawa z dnia 6 czerwca 1997 r. Kodeks postępowania karnego (Dz.U. Nr 89 poz. 556 ze zm.). Ustawa z dnia 29 sierpnia 1997 r. Ordynacja podatkowa (Dz.U. z 2019 r. poz. 900).

Ustawa z dnia 16 listopada 2000 r. o przeciwdziałaniu praniu pieniędzy oraz finansowaniu terroryzmu (Dz.U. z 2000 r. Nr 116 poz. 1216).

Zbiór Zasad Etyki Adwokackiej i Godności Zawodu (Kodeks Etyki Adwokackiej) uchwalony przez Naczelną Radę Adwokacką [dalej: NRA] 10 października 1998 r. (uchwała $\mathrm{nr}$ 2/XVIII/98) ze zmianami wprowadzonymi uchwałą NRA nr 32/2005 z 19 listopada 2005 r., uchwałami NRA nr 33/2011 - 54/2011 z 19 listopada 2011 r. oraz uchwałą nr 64/2016 NRA z 25 czerwca 2016 r.; tj. na podstawie uchwały nr 52/2011 NRA z 19 listopada 2011 r. obwieszczony 27 lutego 2018 r.

\section{Orzecznictwo}

Wyrok TK z dnia 9 listopada 1993 r. (K 11/93, OTK ZU 1993 Nr 2 poz. 37).

Wyrok TK z dnia 8 grudnia 1998 r. (K 41/97, OTK ZU $1998 \mathrm{Nr} 7$ poz. 117).

Uchwała składu siedmiu sędziów SN z dnia 22 stycznia 2003 r. (I KZP 39/02, LEX nr 57084).

Postanowienie SN z dnia 12 grudnia 2014 r. (SDI 44/14).

Postanowienie SN z dnia 15 listopada 2012 r. (SDI 32/12, OSNSD 2012 poz. 49, LEX nr 1231613).

Postanowienie SN z dnia 31 stycznia 2019 r. (sygn. akt VI KZ2/19), www.sn.pl/orzecznictwo (dostęp: 20.03.2020). 